Received July 28, 1970.

1 Wiersma, C. A. G., J. Marme Biol. Assoc. UK, 38, 143 (1959),

2 Wiersma, C. A. G., and Boettiger, E. G., J. Exp. Biol., 36, 102 (1959).

${ }^{3}$ Hartman, H. B., and Boettiger, E. G., Comp. Biochem. Physiol., 22, 651 (1967).

4 Whitear, M., Nature, 187, 522 (1960).

5 Whitear, M., Phil. Trans. Roy. Soc., B., 245, 291 (1962).

6 Mendelson, M., J. Exp. Biol., 40, 157 (1963).

7 Bush, B. M. H., Comp. Biochem. Physiol., 14, 185 (1965).

Bush, B. M. H., J. Exp. Biol., 42, 285 (1965).

\section{Sharp Increase in Free Circulating Oestrogens Immediately Before Parturition in Sheep}

THE principal oestrogen secreted by the ovary of the nonpregnant ewe is $17 \beta$-oestradiol ${ }^{1}$. After continuous infusion of ${ }^{3} \mathrm{H}-17 \beta$-oestradiol into both pregnant and non-pregnant sheep, oestrone and $17 \alpha$-oestradiol have been isolated from blood as the chief unconjugated radiometabolites ${ }^{2,3}$. In pregnancy, oestrogens are excreted in urine as oestrone and $17 \alpha$-oestradiol conjugates $^{4}$, but calculation of blood steroid concentration from these data ${ }^{4}$ and from the metabolic clearance rate of $17 \beta$-oestradiol ${ }^{2}$ suggested that the circulating concentration of $17 \beta$-oestradiol in the pregnant sheep would be extremely small ( $<20 \mathrm{pg} / \mathrm{ml}$. of plasma). Measurements, therefore, of this steroid in circulating blood of the sheep have not been reported, and the role of oestrogens in late pregnancy and parturition has not been defined clearly. Because a decreasing progesterone block on the myometrial contractile response to oxytocin cannot always account for the onset of parturition ${ }^{5}$, it has become increasingly important to establish any significant changes in oestrogen biosynthesis in late pregnancy. I wish to report a rapid ten-fold increase in the maternal circulating oestrogen on the day before parturition in the sheep, which could provide a positive trigger for the' onset of labour.

The method is based on the radioimmunoassay of Caldwell, Scaramuzzi, Tillson and Thorneycrof ${ }^{6}$, which uses an antiserum prepared against $17 \beta$-oestradiol, but which in our laboratory showed a cross reaction against oestrone $(92 \%)$ and $17 \alpha$-oestradiol $(36 \%)$. The results reported here will be referred to as the values for total unconjugated oestrogens extracted from blood. Unconjugated steroid is generally thought to be the chief biologically active fraction within the total blood pool.

Fig. 1 shows plasma total oestrogens $(\mathrm{pg} / \mathrm{ml}$.) throughout seven pregnancies in five sheep; the day of parturition has been taken as day 0 . The concentration of oestrogens was less than $5 \mathrm{pg} / \mathrm{ml}$. until day -31 , after which it increased slowly to $20-40 \mathrm{pg} / \mathrm{ml}$. by day -5 . In samples taken the day before parturition or on the day of lambing, a peak of free oestrogen concentration was found which varied between $75 \mathrm{pg} / \mathrm{ml}$. and $411 \mathrm{pg} / \mathrm{ml}$, , the latter figure being the mean of six samples taken from one sheep between 0 and $35 \mathrm{~h}$ before birth. By $5 \mathrm{~h}$ after birth the concentration of oestrogen in one sheep had already decreased to $35 \mathrm{pg} / \mathrm{ml}$. from $75 \mathrm{pg} / \mathrm{ml}$. the previous day, and in all but one animal, oestrogens were not detectable by the first day after birth.

Although the actual period of gestation in this series varied between 138 and 148 days, in animals from which samples were taken at lambing there was a marked increase in maternal circulating oestrogens on that day or the preceding day. The concentration of progesterone in the blood is decreasing by this time ${ }^{7}$, and so such an alteration in steroid ratio may be involved in the stimulation of the release of oxytocin $^{8}$, or in the preconditioning of the myometrium to its effects, possibly by modifying the electrolyte balances. It has been postulated that the increased activity of the sheep foetal adrenal gland, which begins 5 days pre-partum, may be involved in the initiation of parturition ${ }^{10}$. This gland may also be involved in the secretion of increased amounts of neutral steroid precursors for placental oestrogen ${ }^{11}$ biosynthesis, using the placental aromatizing enzyme systems. The results reported here suggest that any hypothesis of a foetal-induced mechanism of parturition in the sheep must take into account the very rapid increase in circulating maternal oestrogens that occurs within 2 days of lambing.

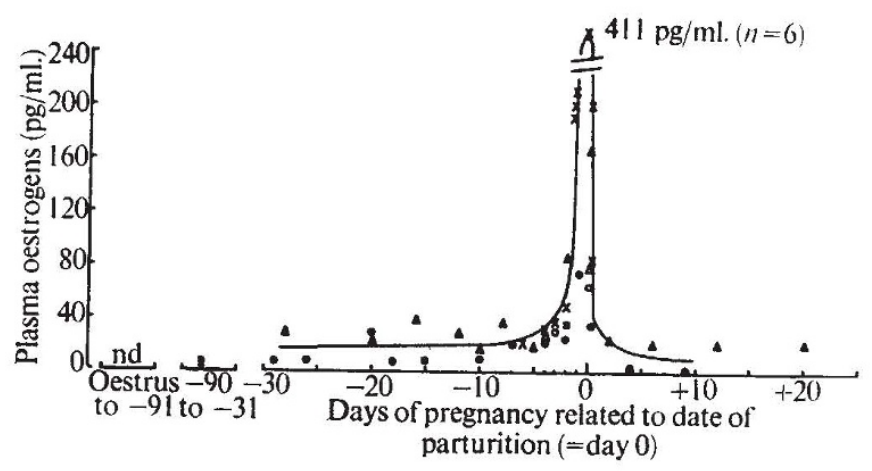

Fig. 1 Oestrogens in sheep peripheral plasma during pregnancy. nd, Not detected $n=12$. Sheep Jane, lambing 1970, gestation 144 days; $\bigcirc$, Jane, 1969, 143; $\Delta$, Di, 1970, 145; $\triangle$, Di, 1969, 138; $\times$, Millicent, 1970, 145; -' Isabella, 1970, 148. The peak of $411 \mathrm{pg}$ is the mean of six samples taken between -35 and $+1 \mathrm{~h}$ in sheep Millicent.

I thank Dr R. B. Heap and Mr F. A. Harrison for advice and interest, and $\mathrm{Mr} \mathrm{A}$. Henville for technical assistance. The antiserum to $17 \beta$-oestradiol was given by Dr B. V. Caldwell, Worcester Foundation for Experimental Biology, Shrewsbury, Massachusetts. This work was supported by a grant from the Science Research Council.

\section{J. R. G. Challis}

Agricultural Research Council, Institute of Animal Physiology, Babraham,

Cambridge

Received August 3; revised October 13, 1970.

${ }^{1}$ Baird, D. T., Goding, J. R., Ichikawa, Y., and McCracken, J. A., J. Endocrinol., 42, 283 (1968).

${ }^{2}$ Challis, J. R. G., Harrison, F. A., and Heap, R. B., Biochem. J., 118, 11P (1970).

${ }^{3}$ Challis, J. R. G., Harrison, F. A., and Heap, R. B., J. Physiol., 210, 93 (1970).

4 Fèvre, J., Piton, C., and Rombauts, P., CR Acad. Sci., 261, 2517 (1965).

3 Porter, D. G., in Progesterone: its Regulatory Effect on the Myometrium, Ciba Foundation Study Group No. 34 (edit. by Wolstenholme, G. E. W., and Knight, J.), 79 (London, Churchill, 1969).

${ }^{6}$ Caldwell, B. V., Scaramuzzi, R. J., Tillson, S. A., and Thorneycroft, I. H., in Immunological Methods in Steroid Determination (edit. by Peron, F. A., and Caldwell, B. V.) (Appleton-CenturyCrofts, New York, in the press).

7 Bassett, J. M., Oxborrow, T. J., Smith, I. D., and Thorburn, G. D., J. Endocrinol., 45, 449 (1969).

${ }^{8}$ Roberts, J. S., and Share, L., Endocrinology, 84, 1076 (1969).

$9 \mathrm{Kao}, \mathrm{C}$. Y., in Cellular Biology of the Uterus (edit. by Wynn, R. M.), 386 (North-Holland, Amsterdam, 1967).

10 Liggins, G. C., in Foetal Autonomy, Ciba Foundation Series (edit. by Wolstenholme, G. E. W., and O'Connor, M.), 218 (Churchill, London, 1969).

${ }^{11}$ Ainsworth, L., and Ryan, K. J., Endocrinology, 79, 875 (1966). 